\title{
LAND CONVERSION AND THE LEVEL COMMUNITY SOCIAL COHESION IN SUB-DISTRICT EMPOANG JENEPONTO REGENCY
}

\author{
Muhammad Faisal \\ Development and Empowerment Study Program, Faculty of Government Politics, IPDN South Sulawesi Campus \\ E-mail: faisalmile69@gmail.com
}

\begin{abstract}
This research aims to find out land conversion that occurs and analyze relationship between the level social cohesion and collective action community after function of the land. The type research used is quantitative research, because takes samples from one population and uses questionnaire basic data collection tool. The number respondents ware 74 people consisting 68 men and 6 women who were captured by convenience, incidental, and purposively sampling techniques taken from those who had sold land and came from various RWs in Empoang subdisrict. Data analysis using SPSS for Windows 20 application. Test hypothesis using Rank Spearman statistical test. The results study found land conversion occurs because land is less productive and also form demographic adaptation and multi-form conversion. Spearman rank test resultsare obtained sig (2-tailed) value 0.013 which is smaller than alpha 0.05. This explains there is positive relationship between the levelof social cohesion and level community involvement collective action, although the correlation coefficient is only 0.286 which explains the relationship between variables is weak. If the level of variable social cohesion increases, level of community involvement in collective action also increases even though the level increase is low due to the typerelationship between the weak variables.
\end{abstract}

Key words: land conversion; social cohesion; collective action

\section{ALIH FUNGSI LAHAN DAN TINGKAT KOHESI SOSIAL MASYARAKAT DI KELURAHAN EMPOANG KABUPATEN JENEPONTO}

\begin{abstract}
ABSTRAK. Penelitian ini bertujuan untuk mengetahui alih fungsi lahan yang terjadi serta menganalisis hubungan antara tingkat kohesi sosial dengan aksi kolektif masyarakat pascaalih fungsi lahan. Jenis penelitian yang digunakan adalah penelitian kuantitatif, karena mengambil sampel dari satu populasi dan menggunakan kuesioner sebagai alat pengumpulan data yang pokok. Besarnya responden adalah 74 orang terdiri atas 68 laki-laki dan 6 perempuan yang dijaring dengan teknik penyampelan convenience, insidental, dan secara purfosif diambil dari mereka yang pernah menjual lahan dan berasal dari berbagai RW di Kelurahan Empoang. Analisis data menggunakan aplikasi SPSS for windows 20. Uji hipotesis menggunakan uji statistik Rank Spearman. Hasil penelitian menunjukkan bahwa alih fungsi lahan yang terjadi karena lahan kurang produktif dan juga sebagai bentuk adaptasi demografi dan konversi multi bentuk. Hasil uji statistik rank spearman diperoleh nilai sig (2-tailed) sebesar 0,013 yang lebih kecil dari alpha 0,05. Ini menjelaskan bahwa terdapat hubungan positif antara tingkat kohesi sosial dengan tingkat keterlibatan masyarakat dalam aksi kolektif, walaupun koefisien korelasinya hanya 0,286 yang menjelaskan bahwa hubungan antar variabel lemah. Jika variabel tingkat kohesi sosial meningkat maka tingkat keterlibatan masyarakat dalam aksi kolektif juga meningkat walaupun tingkat peningkatannya rendah disebabkan oleh jenis hubungan antar variabel yang lemah.
\end{abstract}

Kata kunci: alih fungsi lahan; kohesi sosial; aksi kolektif

\section{INTRODUCTION}

The rapid increase in population has increased the demand for land for housing, services, industry and other public facilities. To fulfill the demand, it can disturb the availability of land, especially agricultural land. The land that was originally used as a place for farming was transformed into a multi-use function. Not only used as settlements but also for other functions such as markets, terminals, industries, shopping centers, and others.

The function of land for the community is as a place to live and a source of livelihood. For farmers, land is a source of food production and survival. For the private sector, land is an asset to accumulate capital. For the government, the land is the sovereignty of a country and for the welfare of its people. There are many interrelated interests in land-use, this results in overlapping interests between actors, namely farmers, the private sector, and the government in utilizing land.
The number of rice fields that are converted into factories or housing and road infrastructure causes employment opportunities in the fields to decrease. Coupled with the use of effective farming tools causes unemployment in the village increases. This phenomenon has created a reduction in the number of workers in the agricultural sector. Moreover, the shrinking of paddy fields has reduced the need for labor in the fields. However, with the reduction in the area of farming, farmers actually reduce their work productivity.

Various regulations have been issued by the government to limit the phenomenon of land use change, but this effort has not been very successful due to the ease of changing the physical condition of rice fields. Regulations aimed at controlling land conversion in general are only appeals and are not supplemented with clear sanctions, so also a conversion permit is a collective decision so it is difficult to track which party is responsible for granting a land conversion permit. Transfer of land functions means changes or adjustments to the designation of use, caused 
by factors that broadly include the need to meet the needs of a growing population and increasing demands for a better quality of life.

Sihaloho (2004) divides land conversion into seven patterns or typologies, namely: (1) gradual conversion of sporadic patterns; influenced by two main factors, namely less / unproductive land and economic urgency of the converters, (2) systematic conversion of berp enclave 'pattern; because the land is less productive, so conversions are carried out simultaneously to increase added value; (3) land conversion as a response to population growth is driven land conversion, hereinafter referred to as demographic adaptation conversion, where with increasing population growth, land is converted to meet residential needs; (4) conversions caused by social problems (social problem driven land conversion); caused by two factors namely economic urgency and changes in welfare, (5) conversion without burden, influenced by the desire to change lives better than current conditions and want to get out of the village, (6) conversion of agrarian adaptation; caused by economic urgency and a desire to change from the community to increase agricultural output; (7) multiform or formless conversion; Conversion is influenced by various factors, in particular the designation of offices, schools, cooperatives, trade, including inheritance systems that are not explained in demographic conversion. One of the factors influencing land conversion according to Mustopa (2012) is the increasing population and industry. This opinion is also supported by the findings of Puspasari (2012) that industrial factors are the main cause of land conversion at the regional level, while at the farmer level is influenced by age, land area, length of education, and farming experience. It was also stressed that land conversion did not affect farmers' income in Kondangjaya Village, Kerawang Timur District, Karawang Regency. Dewi and Iwan Rudianto (2013) in their research in Gunungpati Subdistrict, Semarang City also found that the majority of farmers who lost their paddy fields had decreased income. This is because the level of education and skills of farmers is limited or classified as low so they cannot access formal employment. Besides, Dewi and Iwan Rudianto (2013) found that the presence of differences in economic activity and the inclusion of migrant residents in their area faded the kinship between residents. In contrast to previous studies, this study wants to address the relationship between land use change and social cohesion and the relationship between social cohesion and collective action. That the transfer of land functions causes changes in patterns of social interaction within the community.

The change of function from agricultural land to non-agricultural land which is then referred to as land conversion (conversion) has given rise to the complexity of problems in the community. Conyers (1992) asserted that in a community the factors of language, ethnicity or region of origin, religion, culture, patterns, and life attitudes are usually very valuable factors. Interaction among community members is due to economic interdependence, social relations, or the existence of some form of political organization and the combination of these factors. Interaction is seen as a social process that is faced with changes that occur due to land-use change. As a social process, interaction is one of the factors that influence the social cohesiveness of the community. The higher the interaction, the stronger social cohesion (Faturochman, 2006).

Empoang Urban Village is located in Binamu District, Jeneponto Regency is an area that still has a lot of productive agricultural land. In recent years the area of agricultural land in Empoang has been decreasing. This is caused by the increasingly widespread phenomenon of the conversion of agricultural land into non-agricultural areas in the region. The development of development in Bontosunggu as the Capital of Jeneponto Regency is very rapid. The transfer of the Bontosunggu traditional market to the Karisa traditional market is the beginning of the conversion of agricultural land to non-agriculture. Then followed by the construction of other public facilities such as land transportation terminals, road infrastructure development, including sports buildings and government offices. This situation was also followed by the presence of BTN housing development in Empoang Subdistrict such as BTN Pepabri, BTN Karisa, and others. Likewise, residents' settlements stand along the BontosungguKarisa axis road which is also used as a center for shops and food stalls. This situation has an impact on changes in economic and social aspects such as livelihood patterns and social processes that take place in the community. The increasing land fulfillment, such as for the needs of settlements, places to do economic business, terminals, and other facilities can have an impact on the increasingly narrowing of agricultural land to encourage people to make a living outside the agricultural sector. Changes in economic aspects can be an entry point for new values or norms in a community such as the opening of broad access to information and diverse livelihoods. This situation can change the patterns of interaction of community members. Changes in patterns of interaction can take the form of cooperation or vice versa, for example, the emergence of competition both among members in the community or even with members outside the community.

Changes in economic and social aspects such as patterns of livelihoods or livelihoods and social processes that take place in a rural community, should not harm social cohesion or existing ties and are closely interwoven with the community. Myers (2014) states that social cohesion is a feeling of "we feeling" that unites every member of a community. This sense of belonging makes an individual realize that he is part of a community. Faisal and Umar Nain (2018) emphasized that social cohesion is created along with the emergence of liking among community members and the interactions that occur are dominated by 
cooperation and have goals related to one another.Social cohesion can be seen from the sense of community (sense of community). The theory of community taste as explained by Chavis et al (2008) where the sense of community can be seen from meeting the needs, membership, influence, and sharing emotional relationships. Therefore, changes that occur within the community as a result of land-use change that have an impact on economic and social aspects are expected not to disturb the sense of ownership and sense of community in Empoang Village, Binamu District, Jeneponto Regency, South Sulawesi Province. This study examines how land conversion takes place and the relationship between the level of social cohesion and the level of community involvement in collective action after land-use change.

\section{METHOD}

Types of Research and Data Analysis Techniques. This type of research includes survey research, because it takes samples from one population and uses a questionnaire as a primary data collection tool. Quantitativeresearch can be used for the purpose of explanation (explanatory or confirmatory), namely to explain the causal relationship and hypothesis testing (Singarimbun, 2006). The researcher did not randomize the sample nor control the variables.

Research data were analyzed with descriptive statistics and hypothesis testing using Rank Spearman statistical tests with the help of the SPSS program for Windows 20. According to Trihendradi (2012), the criteria for determining whether the model is fit (the fit between the research model or measurement model with empirical data) is if sig ( 0.000) <alpha (in this study the alpha significance level was set at 5\%).

Definition of Variable Operations. Land conversion is the use of land outside of agricultural activities either partially or completely. Transfer of land functions are grouped into: (i) entirely, respondents sell all land owned; (ii) in part, respondents sell part of their land owned; and (iii) a quarter, respondents sell a quarter of the land they own.

Social cohesion is unity, wholeness, and cohesiveness in an effort to encourage members to remain in a community. According to Chavis et al (2008), social cohesion is measured using four indicators namely Reinforcement of Needs, Membership (involvement as a member of the community), Influence (influencing) and Shared Emotional Connection (sharing emotional contact). Each is defined as follows: Reinforcement of needs: is a condition in which community members get what they need because they have become part of the community; Membership (involvement as community members): people who are members of the community and community members spend a lot of their time and effort to be part of the community; Influence (influence): the ability of a community to influence other communities. In addition, community members also have influence over their community. Shared Emotional Connection (sharing emotional contacts) is that community members enjoy being together in a community and share important events together such as birthdays, weddings, or others.

Collective action is joint action carried out by community members. Collective action consists of: (i) Type: the form of activity of collective action carried out by community members. There are types of collective action, namely: Mutual cooperation (voluntary work), Deliberation, Please help (death, celebration, marriage), or others; (ii) Involvement: the participation of community members in collective action. Involvement in collective action as follows: Donating money, respondents only donate money in each activity; contribute energy, respondents only contribute energy in each activity; contribute ideas, respondents only contribute ideas in each activity, and (iii) Role: as a position of community members in collective action. The role in collective action is as follows: Initiator: respondents who have the initiative; Followers: respondents only act as members who follow directions.

Research Respondents. The research respondents were 74 people (68 men, 6 women) for field research. Age of respondents in the range of 30-70 years. Respondents were selected using convenience, incidental sampling techniques and purposively attempted so that all respondents taken were those who had sold land and came from various RWs in Empoang Subdistrict, Binamu District, Jeneponto Regency.

\section{RESULTS AND DISCUSSION}

The results and discussion in this article focus on land-use change, social cohesion (sense of community) and the relationship between the level of social cohesion (sense of community) and community involvement in collective action after land conversion.

\section{Land Conversion}

The function of land for the community is as a place to live and as a source of livelihood. In land-use, it is known that there are many interests in it. These interests are very dependent on who will use the land. For the government, land is the sovereignty of a country and is certainly used for the welfare of its people. For the private sector land is an asset to accumulate capital (capitalists). Meanwhile farmers, land is a source of food production and survival.

The results of this study explained that of the 74 respondents before land use change there were 54.05 percent who had a livelihood as farmers. As farmers they produce food sources such as rice, corn, green beans, and cassava. After land conversion, some of them changed jobs to become entrepreneurs and as traders, as presented in Table 1 below. 
Table 1. Number and percentage of respondents based on changes in livelihoods before and after land conversion

\begin{tabular}{lcccc}
\hline \multirow{2}{*}{$\begin{array}{c}\text { Main } \\
\text { Livelihoods }\end{array}$} & \multicolumn{2}{c}{$\begin{array}{c}\text { Before Land } \\
\text { Conversion }\end{array}$} & \multicolumn{2}{c}{ After Land Conversion } \\
\cline { 2 - 5 } & $\mathrm{n}$ & $\%$ & $\mathrm{n}$ & $\%$ \\
\hline Entrepreneur & 12 & 16,22 & 32 & 43,24 \\
Farmers & 40 & 54,05 & 10 & 13,51 \\
Trader & 15 & 20,27 & 25 & 33,79 \\
Civil servants & 7 & 9,46 & 4 & 5,41 \\
Retired & 0 & 0 & 3 & 4,05 \\
\hline \multicolumn{1}{c}{ Sum } & 74 & 100 & 74 & 100 \\
\hline
\end{tabular}

Source: Primary Data Though, November 2018

Those who survive as farmers remain 13.51 percent of the 74 respondents. It can be seen in Table 1 that the number of respondents earning a living as entrepreneurs increased to 43.24 percent from the previous one which was only 16.22 percent. Likewise, there was an increase in the number of respondents earning a living as traders, from 20.27 percent to 33.79 percent after land conversion. Changes in livelihood patterns are also followed by changes in income levels. It can be seen in Table 2 that there is a change in income level before land conversion and after land conversion.

Table 2. Number and percentage of respondents' income before and after land conversion

\begin{tabular}{lcccc}
\hline \multicolumn{1}{c}{$\begin{array}{c}\text { Income Level } \\
\text { (IDR) }\end{array}$} & \multicolumn{2}{c}{$\begin{array}{l}\text { Before Land } \\
\text { Conversion }\end{array}$} & \multicolumn{2}{c}{$\begin{array}{c}\text { After Land } \\
\text { Conversion }\end{array}$} \\
\cline { 2 - 5 } & $\mathrm{n}$ & $\%$ & $\mathrm{n}$ & $\%$ \\
\hline $\begin{array}{l}\text { Less than 2.5 } \\
\text { Million } \\
\text { Between 2.5 - 5 } \\
\text { million }\end{array}$ & 40 & 54,05 & 9 & 12,16 \\
More than 5 Million & 15 & 20,27 & 45 & 60,81 \\
\hline \multicolumn{1}{c}{ SUM } & 74 & 25,68 & 20 & 27,03 \\
\hline
\end{tabular}

Source: Primary Data Though, November 2018

If before the conversion of land there were 50.05 percent of respondents who had income levels of less than 2.5 million and after land conversion had decreased to 12.16 percent. The income level between 2.5 million to 5 million has increased from 20.27 percent to 60.81 percent. Likewise, the income level of more than 5 million has increased from 25.68 percent to 27.03 percent. Thus the results of this study explain that land-use change has been a determinant of changes in people's livelihoods from farmers to entrepreneurs and traders which also have an impact on increasing their income levels. This can be understood because their paddy fields are still dependent on the rainy season for irrigation needs so that they harvest only once a year. After they change their livelihoods from farmers to entrepreneurs or traders, even though there is still a risk of loss, the opportunity for greater profits. After working as an entrepreneur or trader every day there is a different income when working as a paddy farmer who harvests once a year.

Associated with the opinion of Sihaloho (2004) which divides land conversion into seven patterns or typologies, of the seven typologies three patterns correspond to the type of land-use change in Empoang Urban Village, Binamu District, Jeneponto Regency. That the paddy fields in Empoang Village are rain-fed, so they are less productive. This is in accordance with the classification of Sihaloho (2004) who called it a systematic 'patterned' conversion which according to him this type of conversion was due to less productive land, so the conversion was carried out simultaneously to increase added value. The development of the Karisa Main Market on Pahlawan Street-Karisa Bontosunggu followed by the construction of infrastructures such as roads, terminals and shopping centers is an effort of the regional government to increase added value other than as an urban development effort.

Still according to Sihaloho (2004) that the pattern of land conversion is in response to population growth is driven land conversion, which he further refers to as demographic adaptation conversion, where with increasing population growth, land is converted to meet housing needs. Population growth in Empoang Sub-district of Binamu District is shown in the following Table 3:

Table 3. The population of Binamu district according to Village / Subdistrict in 2012-2016

\begin{tabular}{|c|c|c|c|c|c|}
\hline Village/Subdistrict & 2012 & 2013 & 2014 & 2015 & 2016 \\
\hline 01. Biringkassi & 3509 & 3544 & 3576 & 3610 & 3643 \\
\hline 02. Pabiringa & 6252 & 6314 & 6372 & 6433 & 6492 \\
\hline 03. Panaikang & 2358 & 2381 & 2403 & 2426 & 2448 \\
\hline 04. Monro-Monro & 2756 & 2783 & 2809 & 2836 & 2861 \\
\hline 05. Sidenre & 3229 & 3261 & 3291 & 3322 & 3353 \\
\hline 06. Empoang Selatan & 4823 & 4871 & 4916 & 4963 & 5008 \\
\hline 07. Empoang & 8438 & 8521 & 8600 & 8681 & 8760 \\
\hline 08. Balang Toa & 4462 & 4506 & 4547 & 4591 & 4633 \\
\hline 09. Balang & 4856 & 4904 & 4949 & 4997 & 5042 \\
\hline 10. Balang Beru & 3349 & 3383 & 3414 & 3446 & 3478 \\
\hline 11. Bontoa & 2330 & 2353 & 2375 & 2397 & 2419 \\
\hline 12. Sapanang & 3443 & 3478 & 3509 & 3543 & 3575 \\
\hline 13. Empoang Utara & 3741 & 3778 & 3812 & 3849 & 3884 \\
\hline SUM & 53546 & 54077 & 54573 & 55094 & 55596 \\
\hline
\end{tabular}


Table 3 explains that the population of Empoang has increased from 8438 people in 2012 to 8760 people in 2016. This means that during the 5 year brackets has increased by 322 people or an increase of 3.82 percent. This explains the need to convert demographic adaptation as stated by Sihaloho (2004). As a form of demographic adaptation by the local government in collaboration with housing developers, several housing developments in Empoang Urban Village have been built as an adaptation of housing needs. Emerging various housing complexes such as those known as BTN Pepari, BTN Karisa, and Turatea Housing in response to housing needs. Likewise, there are also settlements along Pahlawan-Karisa Bontosunggu Street which also serve as a center for shops and a number of food stalls and other economic businesses such as workshops and several banks. In addition, several public facilities were also built such as parks, sports buildings, offices of the Regional Leadership Council (DPD) of several political parties and government offices such as the Office of Transportation and the Regional Disaster Management Agency, and the office of the Regional Representative Council (DPRD) of the Jeneponto Regency. This latter form of land conversion by Sihaloho (2004) refers to it as a multi-form or formless conversion that is carried out because it is influenced by various factors.

Moreover, land conversion in Empoang Sub-district of Binamu District is in accordance with the Law of the Republic of Indonesia of 1960 concerning agrarian principles that all land rights have a social function. Article 9 explains that each Indonesian citizen, both male and female, has an equal opportunity for a right to land and to get benefits and results both for himself and his family. Transfer of land functions in Empoang Village is also done in the public interest. The construction of public roads, the Karisa main market, terminals and parks are for public facilities. This means that land conversion is carried out in line with Government Regulation No. 1 of 2011 that the transfer of functions of sustainable agricultural land can only be done by the government or regional government in the context of land acquisition for public use.

The results of this study are also in line with Mustopa's research (2012) in his research on the factors that influence the conversion of agricultural land in Demak Regency, which found that the variable population and the number of industries had a significant and positive influence on land conversion in Demak. Although this research does not examine the effect of the population on land-use change, the construction of various housing shows that the land-use change is carried out in the context of adaptation to the fulfillment of the needs of the residence. However, the results of this study are different or not in line with the research of Dewi and Iwan Rudianto (2013) who found that the majority of farmers who lost their paddy fields had decreased income. The results of this study explain that with the change in livelihood patterns from farmers to entrepreneurs or traders their income levels actually increase, as presented in Table 2 above. For example income between 2.5 million to 5 million before land-use change was only 20.27 percent, increasing in number to 60.81 percent after land-use change. Likewise, the income level of more than 5 million, which is only 25.68 percent, increased to 27.03 percent after land conversion. And income of less than 2.5 million before land conversion as much as 50.05 percent decreased the amount to 12.16 percent after land conversion. So the conclusion is an increase in respondent income after land conversion is done.

The explanation above explains that the land conversion that occurred in Empoang Urban Village, Binamu District, Jeneponto Regency has become a new space for the creation of mutually beneficial interactions. The increase in the level of income of respondents indicates the existence of cooperative group interactions, shared goals and mutual symbiotic relationships. Moreover group dynamics that occur are positive improvements. Under such conditions, Faturochman (2006) calls it cohesiveness will be formed in groups.

\section{Social Cohesion (Sense of Community)}

Social cohesion (sense of community) is a basic requirement for a community. The European Council defines social cohesion as the ability of a society to guarantee the welfare of its members, suppress differences and avoid polarization. In this study, using the theory of Chavis et al (2008) that the sense of community can be seen from meeting the needs, membership, influence, and sharing emotional relationships.

Meanwhile, Faturochman (2006) said that a group is said to be cohesive if it has several characteristics, one of which is interaction within a group dominated by cooperation rather than competition. The results of this study as presented in Table 4 explain that the intensity of interactions of the research respondents was high at 54.05 percent and classified as low at only 12.17 percent.

Table 4. Number and percentage of respondents based on the intensity of interaction

\begin{tabular}{ccc}
\hline $\begin{array}{c}\text { Interaction } \\
\text { Intensity }\end{array}$ & $\mathrm{n}$ & Percentage \\
\hline High & 40 & 54,05 \\
Is & 25 & 33,78 \\
Low & 9 & 12,17 \\
\hline SUM & 74 & 100 \\
\hline
\end{tabular}

Source: Primary Data Though, November 2018

The results of this study also found that the highest forms of interaction were never conflicted between fellow citizens reaching 98.65 percent, never competing for 90.59 percent, and always working together reaching 79.73 percent. This fact explains that interaction within groups in the community in Empoang Urban Village is dominated by cooperation, not competition or conflict. Thus it can be said that the people in Empoang Village are cohesive, 
which can also be seen from caring, greeting each other, helping each other, helping, and visiting each other.

Furthermore, the sense of community (sense of community) with four indicators can be seen in the following Table 5.

Table 5 explains that indicators of fulfillment include high categories up to 100 percent, member involvement also reaches 100 percent, and emotional contact sharing also reaches 100 percent. While providing an influence also included in the high category which reached 97.30 percent. Meeting needs is a condition in which community members get what they need because they have become part of their community. Involvement of members are people who spend a lot of their time and effort to be part of their community. Giving influence is the ability of citizens to influence other members of the community. Whereas sharing emotional contact is community members enjoying being together and sharing important events together.

All the needs of residents are met starting from the needs of clothing, food, and shelter. In the area of landuse change various kinds of shopping centers that provide various types of residents' needs. There are Misipasaraya stores, Indomaret stores, Alfamart and AlfaMidi. Likewise, several banks have also been established, such as Bank Rakyat Indonesia (BRI), Bank Nasional Indonesia (BNI), and the South Sulawesi Branch Development Bank Jeneponto, all of which are located in Empoang Village. Even in various street corners built Automated Teller Machines (ATMs) or Automated Teller Machines intended for residents to facilitate access to bank services. In addition, there are also two public fueling stations (SPBU) that provide various types of fuel needs such as diesel, premium, pertalite, and Pertamax. In various places in Empoang Kelurahan there are shops that prepare building materials for residents to meet the needs of the board.

The results of this study indicate the high involvement of members in various types of activities in the community. As explained in Table 5 that member involvement reached 100 percent. The usual types of activities in the community are community service or mutual assistance, consultation and help. Another form of community involvement is to contribute to other citizens in the form of ideas, energy, and in the form of money. Moreover, they also participate in their community both as initiators and as followers in every activity. All respondents in this study acknowledged that they were involved in the membership of their community because in principle they were the original inhabitants of Turatea who lived in
Empoang Village in Binamu District, Jeneponto Regency.

Giving influence is the ability of citizens to influence others. In Table 5 there are 97.30 percent. Most of them have paddy fields above 0.25 ha. Among them were hiring farm laborers in managing their fields. As landowners they influence other residents, especially to farm laborers. Moreoverto the ownership of paddy fields, their influence is also due to their old age. Figure 1 below describes the age of the respondent.

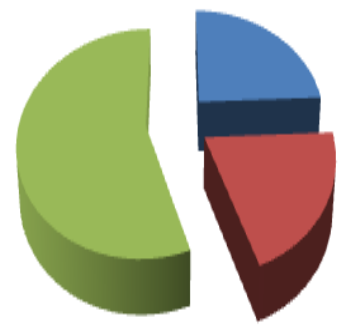

Less than 50 years

Between $50-60$ years

Morethan 60 years

Source: Primary Data Though, November 2018

\section{Figure 1. Description of respondent age}

In the graph above it can be seen that as many as 55.41 precents of respondents who are over 60 years old even there is 1 respondent who has aged 70 years. These ages in the Turatea Jeneponto community are seen as elders who can influence the conditions in their environment. Jeneponto people call them king who can take advice or advice during of the community. Meanwhile, there is 2.70 percent which is in the low category in terms of giving influence. This is due to the relatively young age and also some who do not own land because all the land has been sold.

Next, share emotional contact within the community and share important events together. This can be seen from the residents often gather with other residents, hope forever to live in Empoang Village, residents care about each other, share important events such as weddings, circumcision, aqiqah, birthdays, including coming to mourn when residents are hit by calamities, and etcetera. The results of the study in Table 5 explain that 100 percent of respondents share emotional contact with other residents classified as high. Every time an event is held, the residents compete to get involved in it, such as at weddings, mutual assistance, including when they come to deliver if there are residents who perform the pilgrimage to Sudiang, Makassar City. Likewise, they are very united to attend the program of takziah if there are residents who have been killed. This can happen because they have close

Table 5. Number and percentage of respondents based on social cohesion level

\begin{tabular}{|c|c|c|c|c|c|c|c|c|}
\hline \multirow[t]{2}{*}{ Category } & \multicolumn{2}{|c|}{$\begin{array}{l}\text { Reinforcement of } \\
\text { Needs }\end{array}$} & \multicolumn{2}{|c|}{ Membership } & \multicolumn{2}{|c|}{ Influence } & \multicolumn{2}{|c|}{$\begin{array}{c}\text { Shared Emotional } \\
\text { Connection }\end{array}$} \\
\hline & $\mathrm{n}$ & $\%$ & $\mathrm{n}$ & $\%$ & $\mathrm{n}$ & $\%$ & $\mathrm{n}$ & $\%$ \\
\hline High & 74 & 100,0 & 74 & 100,0 & 72 & 97,30 & 74 & 100,0 \\
\hline Low & 0 & 0,0 & 0 & 0 & 2 & 2,70 & 0 & 0,0 \\
\hline SUM & 74 & 100 & 74 & 100 & 74 & 100 & 74 & 100 \\
\hline
\end{tabular}


family relations and have the same background as the native Turatea Jeneponto.

Referring to the description above, it is said that the interaction that occurs between residents in Empoang Village is associative. This can be seen from the cooperation, please help, care for each other, greet each other, and mutual understanding between residents. Soekanto (2005) calls it an associative process (processes of association), which means building or mutually showing positive roles and contributions between interacting parties, not vice versa showing negative roles and contributions between interacting parties. This situation according to Faturochman (2006), is a cooperative interaction that occurs, with a shared goal and interdependence among citizens. So that in the end the exchange is quite intensive and there are similarities between them so that groups are formed. So the group that has formed generally develops in the direction of the dynamics that occur within the group. Furthermore, Faturochman (2006) mentioned that group dynamics that occur are positive escalations and in such conditions cohesiveness within groups will form. With cohesion, it becomes the glue that holds the community together, builds harmony and community spirit, and is committed to achieving common goals. The results of this study support the opinion of Ritzen et al (2000) which states social cohesion as a condition in which a group of people in a geographical area shows the ability to collaborate and produce a climate for change.

The value of social cohesion indicators that are categorized as high such as meeting needs, membership, influencing, and sharing emotional contact is expected to change the issues that are considered to be prone to conflict. Emphasis on social cohesion can help increase trust, associations between groups, and communication networks between different groups of religions, races, lifestyles, and levels of economic progress. The development of social cohesion can be in the form of bridging cooperation, mutual understanding, and the creation of common interest can be the basis for maintaining sustainable wholeness.

Social cohesion can help increase trust. This explains that the creation of social cohesion in the community will also create strong social capital in a community group. It is said so because trust is a dimension of social capital, in addition to networking and norms of reciprocity. Trust (trust) is understood not just appear. He needs time to proceed to create mutual trust. If the process of time travel does not create mutual trust, then the possibility that happens is a dispute or even conflict. Therefore building social cohesion is an important and absolutely necessary element in maintaining the continuity of a harmonious economic endeavor in society.

\section{The Relationship Between the Level of Social Cohesion and the Level of Community Involvement in Collective Action}

The hypothesis tested is that there is a positive relationship between the level of social cohesion and the level of community involvement in collective action. Spearman rank statistical test results obtained a sig (2-tailed) value of 0.013 which is smaller than alpha 0.05 . This explains that there is a positive relationship between the level of social cohesion and the level of community involvement in collective action, even though the correlation coefficient is only 0.286 which explains that the relationship between variables is weak. This explains that if the variable level of social cohesion increases, the level of community involvement in collective action also increases even though the level of increase is low due to the type of relationship between the weak variables. The level of social cohesion is measured based on four indicators namely meeting needs, membership, influencing, and sharing emotional contact. While the variable level of community involvement in collective action is measured from three indicators namely the type of activity, involvement, and role. The type of activity in question is community service / mutual assistance, deliberation, and help. Meanwhile, involvement is to contribute ideas, contribute energy, and contribute money. Furthermore, the role is divided up as an initiator and as a follower (adherent).

Taking into account the results of hypothesis testing that have a positive relationship between the level of social cohesion and community involvement in collective action even though a weak relationship strength index (IKH) can be explained that each indicator of the level of social cohesion is positively related to indicators on the variable level of community involvement in collective action . The weak relationship shows that even though three of the four indicators of social cohesion level reaching 100 percent in the high category does not automatically make the variable level of participation in collective action also 100 percent in the high category. In reality on the ground it was found that the level of participation in collective action was still 6.76 percent which was categorized as low even though it had already reached 93.24 percent which was categorized as high. Likewise, it was also found that the types of activities such as deliberation still 2.70 percent of respondents who had never participated and 8.11 percent who gave answers rarely participated in the deliberations. The weak relationship can also be explained that community involvement in contributing ideas is 6.76 percent who choose answers never and 16.22 percent of respondents who give rare answers. Likewise, community involvement in contributing labor was 4.05 percent giving sparse answers and 40.54 percent choosing frequent answers. Even those who always provide power are only 55.41 percent of the 74 respondents. Also found was the fact that there was 6.76 percent of respondents who had never acted as initiators and those who provided answers were rarely 10.81 percent. Furthermore, the role of followers was only 16.22 percent of respondents who gave answers always, answers were often 40.54 percent and there was even 24.32 percent who were never followers, including 18.92 percent who gave rare answers. This explains that 
the relationship between the level of social cohesion and the level of community involvement in collective action is also influenced by various factors, especially aspects that are inherent in their respective residents such as the age and education level of each respondent. They are already elderly have chosen not to do activities outside the home. Therefore they decided not to participate in joint activities enough to choose to contribute ideas or enough money. Likewise those who have low education are unable or reluctant to provide initiatives to other citizens. Moreover, community involvement in collective action is also due to the strong ties of brotherhood between them that make them share common values and norms.

The positive relationship between the level of social cohesion and the level of community involvement in collective action shows that cultural values are shared together in their living systems and reciprocity is created. Cohesiveness between citizens is needed not only to smooth economic progress but also to make life and livelihood more orderly, comfortable, peaceful and prosperous.

\section{CONCLUSION}

The land-use change in Empoang Urban Village began massively in 2000, since the Bontosunggu market was moved to become the Karisa parent market, followed by infrastructure development such as roads, terminals, housing and shopping centers. The transfer of land functions has changed the livelihood patterns of the agricultural sector to the non-agricultural sector. Changes in livelihood patterns also have an impact changes in the level of income to be greater. The level of community social cohesion is high. Social interactions that have been built long before land conversion did not change after the conversion. The length of their stay, and the strong ties of brotherhood and blood relations between them resulted in the community becoming cohesive. There is a positive relationship between the level of social cohesion and the level of community involvement in collective action, but the Relationship Strength Index (IKH) is weak. The created social cohesion causes citizens not to be individualistic which impacts on the ease of involving themselves in collective actions. Although it is known that characteristics of citizens such as age and education level contribute to the level of their involvement in collective action.

\section{ACKNOKLEDGMENT}

Thank you to the Director of the IPDN South Sulawesi Campus for providing financial support to the implementation of this research. Thanks also go to the Jeneponto Regency Government for granting this research permit to be carried out and also thank the respondents who participated in responding to the research questionnaire.

\section{REFERENCES}

Conyers., D. (1992). Perencanaan Sosial di Dunia Ketiga: Suatu Pengantar (Terj: $\quad$ Susetiawan). Yogyakarta: Gajah Mada University Press.

Chavis, L. \& Acosta (2008). The Sense of Community (SCI) Revised: The Reliability and Validity of the SCI-2. Paper presented at the $2^{\text {nd }}$ International Community Psychology Conference, Portugal: Lisboa.

Dewi \& Rudianto, I. (2013). Identifikasi Alih Fungsi Lahan Pertanian dan Sosial Ekonomi Masyarakat di Daerah Pinggiran Kecamatan Gunungpati Semarang. Jurnal Wilayah dan Lingkungan, 1, (2), 175-188.

Faisal \& Nain, U. (2018). Implikasi Pelaksanaan Program Dana Desa Terhadap Kohesi Sosial di Desa Tamalate Kabupaten Takalar. Sosiohumaniora. 20, (3), 222-230.

Faturochman. (2006). Pengantar Psikologi Sosial (Introduction to Social Psychology), Yogyakarta: Pustaka.

Mustopa,(2012). AnalisisFaktor-FaktoryangMempengaruhi Alih Fungsi Lahan Pertanian di Kabupaten Demak. Skripsi. Semarang: Universitas Negeri Semarang.

Myers. \& David, G. (2014). Social Psychology (10 edition). Jilid 1. Jakarta: Penerbit Salemba Humanika.

Puspasari, A. (2012). Faktor-Faktor yang Mempengaruhi Alih Fungsi Lahan Pertanian dan Dampaknya Terhadap Pendapatan Petani. Skripsi., Departemen Ekonomi Sumber Daya dan Lingkungan. Bogor: Fakultas Ekonomi dan Manajemen. Institut Pertanian Bogor.

Ritzen J., Easterly, W. \& Woolcock, M. (2000). On "Good" Politicians and "Bad" Policies-Social Cohesion, Institutions and Growth. (English) Policy, Research working paper; no. WPS 2448 Washington, D.C.: World Bank Group. http://documents.worldbank. org/curated/en/930241468739559571/On-goodpoliticians-and-bad-policies-social-cohesioninstitutions-and-growth

Sihaloho, M. (2004). Konversi Lahan Pertanian dan Perubahan Struktur Agraria. (Tesis). Fakultas Pascasarjana. Bogor. Institut Pertanian Bogor.

Singarimbun, M. \& Effendi, S. (2006). Metode Penelitian Survai. Jakarta: LP3ES.

Soekanto, S. (2005). Sosiologi Suatu Pengantar. Jakarta: Rajawali Press.

Trihendradi, C. (2012). Step by Step SPSS 20 Analisis Data Statistik, Yogyakarta: Penerbit C.V. Andi Offset. 